\title{
Non-selective beta blockers inhibit angiosarcoma cell viability and increase progression free- and overall-survival in patients diagnosed with metastatic angiosarcoma
}

\author{
Clarissa N. Amaya ${ }^{1}$, Mariah Perkins ${ }^{2}$, Andres Belmont ${ }^{3}$, Connie Herrera ${ }^{3}$, Arezo \\ Nasrazadani ${ }^{3}$, Alejandro Vargas ${ }^{3}$, Thuraieh Khayou ${ }^{1}$, Alexa Montoya ${ }^{1,4}$, Yessenia \\ Ballou1 ${ }^{1}$ Dana Galvan ${ }^{3}$, Alexandria Rivas ${ }^{1}$, Steven Rains ${ }^{1}$, Luv Patel ${ }^{3}$, Vanessa \\ Ortega $^{1}$, Christopher Lopez ${ }^{1}$, William Chow $^{5}$, Erin B. Dickerson ${ }^{6,7}$ and Brad A. \\ Bryan $^{1,3}$ \\ ${ }^{1}$ Department of Biomedical Sciences, Texas Tech University Health Sciences Center, El Paso, TX, USA \\ 2 Department of Biochemistry, Baylor University, Waco, TX, USA \\ ${ }^{3}$ Paul L. Foster School of Medicine, Texas Tech University Health Sciences Center, El Paso, TX, USA \\ ${ }^{4}$ Department of Biology, University of Texas, EI Paso, TX, USA \\ ${ }^{5}$ Mohs Micrographic Surgery and Cutaneous Oncology, San Leandro, CA, USA \\ ${ }^{6}$ Department of Veterinary Clinical Sciences, University of Minnesota, St. Paul, MN, USA \\ ${ }^{7}$ Masonic Cancer Center, University of Minnesota, Minneapolis, MN, USA \\ Correspondence to: Brad A. Bryan, email:brad.bryan@ttuhsc.edu
}

Keywords: angiosarcoma, propranolol, beta blocker, sarcoma

Received: January 09, $2018 \quad$ Accepted: March 02, $2018 \quad$ Published: April 29, 2018

Copyright: Amaya et al. This is an open-access article distributed under the terms of the Creative Commons Attribution License 3.0 (CC BY 3.0), which permits unrestricted use, distribution, and reproduction in any medium, provided the original author and source are credited.

\section{ABSTRACT}

Patients with metastatic angiosarcoma undergoing chemotherapy, radiation, and/or surgery experience a median progression free survival of less than 6 months and a median overall survival of less than 12 months. Given the aggressive nature of this cancer, angiosarcoma clinical responses to chemotherapy or targeted therapeutics are generally very poor. Inhibition of beta adrenergic receptor ( $\beta$-AR) signaling has recently been shown to decrease angiosarcoma tumor cell viability, abrogate tumor growth in mouse models, and decrease proliferation rates in preclinical and clinical settings. In the current study we used cell and animal tumor models to show that $\beta-A R$ antagonism abrogates mitogenic signaling and reduces angiosarcoma tumor cell viability, and these molecular alterations translated into patient tumors. We demonstrated that non-selective $\beta-A R$ antagonists are superior to selective $\beta-A R$ antagonists at inhibiting angiosarcoma cell viability. A prospective analysis of nonselective $\beta$-AR antagonists in a single arm clinical study of metastatic angiosarcoma patients revealed that incorporation of either propranolol or carvedilol into patients' treatment regimens leads to a median progression free and overall survival of 9 and 36 months, respectively. These data suggest that incorporation of non-selective $\beta$-AR antagonists into existing therapies against metastatic angiosarcoma can enhance clinical outcomes.

\section{INTRODUCTION}

Angiosarcomas are rare vascular tumors of aberrant endothelial histology that exhibit an aggressive and often highly lethal natural course. These tumors can manifest at various sites on the body, but are most frequent in the skin, soft tissue, liver, breast, spleen, bone, or heart $[1,2]$. Metastatic angiosarcoma patients face a dismal median progression free survival (PFS) of 3 to 6 months and median overall survival (OS) of 3 to 12 months [38]. Overall treatment response rates to chemotherapy or targeted therapeutics in patients with metastatic disease 
are generally between $10-20 \%$ [6, 7, 9-11], and there are no established treatment guidelines for metastatic disease. Because of the poor prognosis of patients with metastatic angiosarcoma, novel therapies that improve outcome are desperately needed.

Several recent studies have reported beta adrenergic receptor $(\beta-A R)$ expression across diverse tumor types [12-23], and a growing body of literature suggests a role for $\beta$-AR signaling in regulating multiple hallmarks of benign and malignant tumors [24-28]. Inhibition of $\beta$-AR signaling by receptor antagonists (beta blockers) has become the gold standard treatment for the benign vascular tumor infantile hemangioma [27, 29], in part through disrupting tumor cell proliferation [30]. By translating these findings to malignant angiosarcomas, we showed that propranolol exhibits selective cytotoxicity and tumor suppressive ability against these tumors [21]. Clinical translation of propranolol in combination with chemotherapy drugs has generated overwhelming clinical responses in all reports to date of its use in angiosarcoma patients [31-38]. Among these studies, Pasquier et al. combined propranolol and the microtubuletargeting agent vinblastine in seven patients with advanced angiosarcomas, and showed that incorporation of propranolol into the chemotherapy regimen leads to a median PFS and median OS at 11 and 16 months, respectively [36]. Collectively, the clinical effectiveness of propranolol against angiosarcomas recently led to its Orphan Drug Designation by the European Medicines Agency (EMA) for use against soft tissue sarcomas.

In addition to vascular tumors, $\beta$-AR antagonists have shown preclinical efficacy against a variety of malignant tumors including breast cancer $[10,15$, 39-41], neuroblastoma [42], and melanoma [43-48]. Retrospective analyses of patient data have also revealed a strong correlation between reduced tumor progression, metastasis, and mortality, and the use of $\beta$-AR antagonists in breast, ovarian, and prostate cancer patients, as well as melanoma patients $[15,49-58]$. Prospective clinical studies have reported that propranolol use results in a reduced breast tumor proliferation rates [15], and, when combined with COX-2 inhibitors, $\beta-\mathrm{AR}$ antagonists inhibit multiple cellular and molecular pathways related to metastasis and disease recurrence [59].

In the current study, we evaluated the efficacy of selective (targeting only one $\beta$-AR) and non-selective (targeting multiple $\beta$-ARs) beta blockers using in vitro angiosarcoma models. We then quantified clinical outcomes of patients with metastatic disease prescribed non-selective beta blockers in combination with standard treatment regimens.

\section{RESULTS}

$\beta$-AR antagonism disrupts sarcoma cell viability. We have previously shown that $\beta$-AR antagonists inhibit the viability of angiosarcoma cells and limit tumor progression $[21,32,36]$. We expanded these findings to additional angiosarcoma and hemangiosarcoma cells lines, revealing dose-dependent decreases in cell viability in response to propranolol for all cell lines with the exception of SB-HSA, a hemangiosarcoma line (Figure 1A). Treatment of SVR cells with propranolol reduced the expression of cyclins and cyclin dependent kinases, and increased the expression of cyclin dependent kinase inhibitors (Figure 1B), confirming the impact of propranolol at the molecular level. We then used antibody arrays to assess signaling alterations induced after 1 hour treatment with propranolol, revealing activation of cell stress/survival mediators including AKT and p53, and inhibition of multiple MAPK mediators such as p42, p44, JNK, and p38 (Figure 1C). A subset of these signaling alterations was confirmed in mice bearing SVR angiosarcoma xenografts treated with $15 \mathrm{mg} / \mathrm{kg}$ propranolol for 15 minutes. A comparison with tumors from sham treated controls revealed decreased mitogenic p42/44, JNK/SAPK, and p38 phosphorylation and increased apoptotic p53 phosphorylation (Figure 1D). We confirmed these results in tumor samples obtained from an angiosarcoma patient taken before and one week after treatment with propranolol monotherapy. Evaluation of the expression of levels of phosphorylated p44/42, JNK/ SAPK, and p38, as well as the apoptotic regulator p53 by IHC showed the levels of all three mitogenic regulators were markedly reduced following propranolol, while the level of phosphorylated p53 was increased (Figure 1E).

Non-selective $\beta$-AR antagonists are superior to selective $\beta$-AR antagonists for inhibiting angiosarcoma viability. Propranolol is a non-selective $\beta$-AR antagonist that classically inhibits both $\beta 1-A R$ and $\beta 2-A R$. Our lab and others have previously shown that non-selective $\beta$-AR antagonists are superior to selective $\beta$-AR antagonists with regard to decreasing tumor cell proliferation and enhancing clinical outcome in breast, liver, and ovarian cancer $[15,57,58]$. To determine if a similar outcome could be observed in angiosarcoma models, we evaluated the viability of two angiosarcoma cell lines following treatment with propranolol, $\beta 1-\mathrm{AR}$ selective antagonists (esmolol and atenolol), or $\beta 2-\mathrm{AR}$ selective antagonists (butoxamine and ICI-118,551). $\quad \beta 3$-AR selective antagonists were not evaluated since selective antagonists targeting this receptor are not clinically available to patients. While moderate decreases in cell viability were observed following treatment of the angiosarcoma cells with the selective receptor antagonists, none of the selective antagonists were as effective as propranolol (Figure 2A \& 2B). To determine if the observed difference was due to activation or inhibition of different cell signaling pathways, SVR cells were treated with non-selective or selective antagonists for 1 hour and mitogenic and survival signaling changes were evaluated using antibody arrays. Compared to control samples, 
the majority of the protein phosphorylation events were consistent between propranolol and the selective $\beta$-AR antagonists. The major exceptions to this involved propranolol-mediated upregulation of AKT and p53 phosphorylation, which did not occur upon treatment with the selective $\beta-\mathrm{AR}$ antagonists (Figure $2 \mathrm{C}$ ).

Non-selective $\beta$-AR antagonists extend progression free and overall survival in patients with metastatic angiosarcoma. Patients with an initial diagnosis of metastatic angiosarcoma were prescribed the non-selective beta blockers propranolol or carvedilol in addition to their anti-cancer treatment regimen. Six women and three men were included in this study, with a median age of 53.7 (range=34-75). Each patient was given propranolol (20 to $100 \mathrm{mg}$ per day; $\mathrm{n}=8$ ) or carvedilol $(6.25 \mathrm{mg}$ per day; $\mathrm{n}=1$ ) in combination with treatment protocols, which varied by treating oncologist (Table 1). Patients treated with non-selective $\beta$-AR antagonists were chosen for this study based on the stronger efficacy observed in our preclinical models of angiosarcoma (Figures 1 and Figure 2). A single patient declined chemotherapy or radiation, and was only prescribed propranolol and supportive care. All patients were monitored between the years of 2013 to 2017. PFS and OS rates were improved in patients taking $\beta$-AR antagonists relative to the historical controls [4]. Specifically, administration of $\beta-A R$ antagonists in combination with anti-cancer therapies resulted in a median PFS of 9 months verses previous reports of 3 to 6 months (Figure 3A), and a median OS of 36 months verses documented reports of 12 months (Figure 3B). The correlation coefficient between daily dose of propranolol and PFS was 0.25 , suggesting a very weak/absent relationship between the doses of propranolol used in this study and clinical outcomes.

\section{DISCUSSION}

The data presented in this study demonstrate that non-selective $\beta$-AR antagonists effectively inhibit tumor cell viability and mitogenic signaling in angiosarcomas. Furthermore, incorporation of non-selective $\beta$-AR antagonists into the standard treatment of patients with metastatic angiosarcoma substantially increased PFS and OS compared to historical controls.

The influence of $\beta$-AR signaling on non-diseased and tumor cell proliferation rates was reported in the literature more than half a century ago [28]. We have previously reported in angiosarcoma and breast cancer patient case studies that neoadjuvant administration of propranolol alone reduced the tumor proliferative index based on quantification of tumor Ki-67 levels [15, 32]. With the exception of the propranolol-resistant SB cell line, our current data demonstrates that concentrations of propranolol as low as $10 \mu \mathrm{M}$ reduces angiosarcoma cell viability between $6 \%$ to $53 \%$ compared to controls, with increasingly stronger anti-proliferative affects observed at elevated concentrations of the drug. We validated these findings at the molecular level using in vitro assays, a xenograft tumor model, and patient tumor analysis to demonstrate that propranolol consistently reduces mitogenic signaling and increases apoptotic signaling in angiosarcomas. While our results show that $\beta$-AR antagonists disrupt tumor cell function, the dramatic anti-tumor responses observed following administration of $\beta$-AR antagonists in angiosarcoma patients may also be due, at least in part, to effects on cells within the tumor stroma. For example, $\beta$-AR stimulation increases cellular transformation of fibroblast cells in soft agar [74], suggesting that catecholamine signaling could directly influence tumor stromal behavior. $\beta$-AR antagonists also potentiate the anti-angiogenic effects of chemotherapy agents [36] and suppress cell cycle progression and chemotactic motility in endothelial cells [75], suggesting an anti-angiogenic function for these drugs. Catecholamine stimulation of $\beta$-ARs disrupts immune cell differentiation, impairs the cytotoxicity of natural killer cells and expansion of memory CD8+ T-cells, and alters T-helper cell responses [76-83]. Recently, propranolol has been shown to influence the activity of the immune system where it facilities the conversion of tumors to an immunologically active tumor microenvironment with increased T-cell infiltration and decreased immunosuppressive PD1 expression [44, 84], suggesting that adrenergic antagonists may be an effective adjuvant to immunotherapy.

Retrospective studies in breast, ovarian, and liver cancer suggest that non-selective $\beta-A R$ antagonists such as propranolol are more effective against tumors than selective receptor antagonists, which target single $\beta$-AR receptors $[15,57,58]$. The current data in angiosarcoma validates previous findings from other cancer types by showing that propranolol more effectively reduces tumor cell viability than $\beta 1$ - or $\beta 2$-AR-selective antagonists. At the molecular level, non-selective and selective antagonists similarly affect post-translational modifications of mitogenic regulators; however, only propranolol induced phosphorylation of AKT and p53 proteins, suggesting a differential regulation of survival/ apoptotic proteins between receptor-selective and nonselective drugs. While all three $\beta$-AR receptors are expressed across a variety of cancer types [23], including angiosarcoma $[30,32]$, the individual contribution each receptor makes to the overall oncogenic processes is not known. It is possible that selective antagonism of a single $\beta$-AR is compensated by other expressed $\beta$-ARs, thus explaining the insufficiency of selective antagonists to recapitulate the anti-proliferative effects of non-selective antagonists. 
Table 1: Clinical information for metastatic angiosarcoma patients

\begin{tabular}{|c|c|c|c|c|c|}
\hline Sex & Primary & Metastases & Treatment & Antagonist & Dose/day \\
\hline $\mathrm{F}$ & Breast & Skull & $\begin{array}{l}\text { Doxorubicin, } \\
\text { Cyclophosphamide, } \\
\text { Radiotherapy }\end{array}$ & Propranolol & $60 \mathrm{mg}$ \\
\hline M & Spleen & $\begin{array}{l}\text { Bone marrow, } \\
\text { liver }\end{array}$ & $\begin{array}{l}\text { Doxorubicin, } \\
\text { Radiotherapy, Surgery }\end{array}$ & Carvedilol & $6.25 \mathrm{mg}$ \\
\hline $\mathrm{F}$ & Breast & $\begin{array}{l}\text { Lymph nodes, } \\
\text { chest cavity }\end{array}$ & $\begin{array}{l}\text { Paclitaxel, Ifosfamide, } \\
\text { Carboplatin }\end{array}$ & Propranolol & $40 \mathrm{mg}$ \\
\hline M & Pleura & $\begin{array}{l}\text { Lymph nodes, } \\
\text { bone }\end{array}$ & Doxorubicin & Propranolol & $100 \mathrm{mg}$ \\
\hline $\mathrm{F}$ & Breast & Lungs & $\begin{array}{l}\text { Paclitaxel, } \\
\text { Cyclophosphamide }\end{array}$ & Propranolol & $60 \mathrm{mg}$ \\
\hline M & Liver & Spleen, Lungs & $\begin{array}{l}\text { Doxorubicin, } \\
\text { Radiotherapy }\end{array}$ & Propranolol & $40 \mathrm{mg}$ \\
\hline $\mathrm{F}$ & Breast & Liver & $\begin{array}{l}\text { Doxorubicin, } \\
\text { Gemcitabine }\end{array}$ & Propranolol & $20 \mathrm{mg}$ \\
\hline $\mathrm{F}$ & Breast & $\begin{array}{l}\text { Brain, Bone, } \\
\text { Lungs, } \\
\text { Maxillary Sinus, } \\
\text { Thigh }\end{array}$ & $\begin{array}{l}\text { Doxorubicin, Ifosfamide, } \\
\text { Paclitaxel, Gemcitabine, } \\
\text { Radiotherapy }\end{array}$ & Propranolol & $40 \mathrm{mg}$ \\
\hline $\mathrm{F}$ & Cardiac & Lungs, Liver & None & Propranolol & $40 \mathrm{mg}$ \\
\hline
\end{tabular}

The data presented in this study revealed that incorporation of non-selective $\beta$-AR antagonism into standard treatment regimens increased PFS and OS from approximately 3 to 6 months and 24 to 33 months, respectively, relative to reported results from several key clinical studies that incorporated only chemotherapy, radiation, and/or surgery [3-8]. The efficacy reported in the current study corroborates data previously published by Pasquier and colleagues showing increased PFS and OS for angiosarcoma patients taking propranolol in combination with chemotherapy [36]. We did not observe a significant correlation between the dose of antagonist and clinical outcome based on PFS, therefore future studies with larger patient cohorts will be needed to optimize dosage. While propranolol led to efficacy when combined with other treatment modalities, we were very surprised to see that when used as a single agent propranolol resulted in sustained disease regression for a patient who declined chemotherapy, radiation, and surgery. While this single instance in no way suggests that patients should opt for adrenergic antagonists in lieu of other established treatment options against metastatic angiosarcoma, this limited observation raises the question if these drugs could be used to extend survival in patients who decline standard treatment and opt for only supportive care.

\section{MATERIALS AND METHODS}

Cell culture and chemicals. SVR angiosarcoma [60, 61] (ATCC \#CRL-2280) and EMMA hemangiosarcoma cells [62] were grown in Dulbecco's Modified Eagle Medium (DMEM) supplemented with 10\% fetal bovine serum (FBS) and penicillin/streptomycin (P/S). COSB hemangiosarcoma [63], SB-HSA hemangiosarcoma cells [64], ISOS-1 angiosarcoma [65], ISO-HAS angiosarcoma [66], and AS5 angiosarcoma cells [67] were grown in EBM-2 Basal Medium (Lonza \#CC-3156) supplemented with EGM2 Bulletkit (Lonza \#CC-4176). All cells were cultured in $37 \mathrm{oC}$ water-jacketed $\mathrm{CO} 2$ incubators maintained for gas, temperature, and humidity. The 

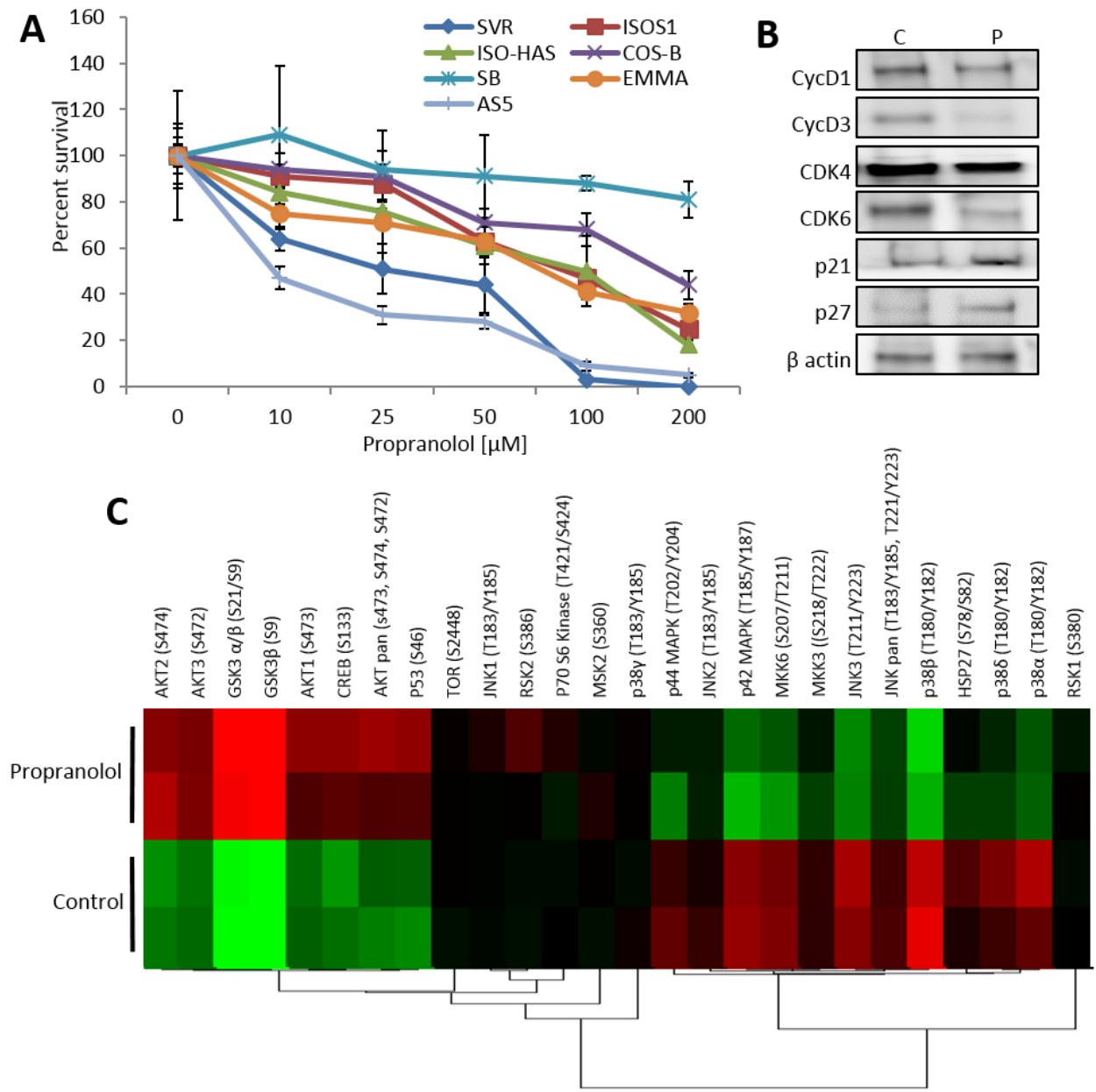

D

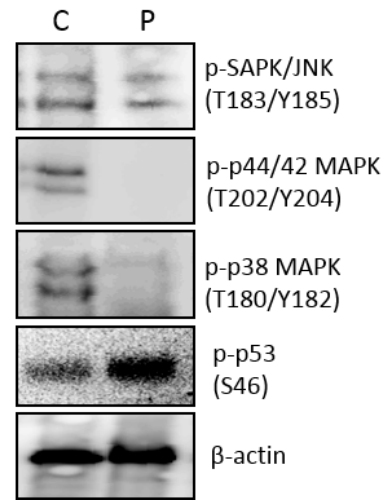

$\mathbf{E}$

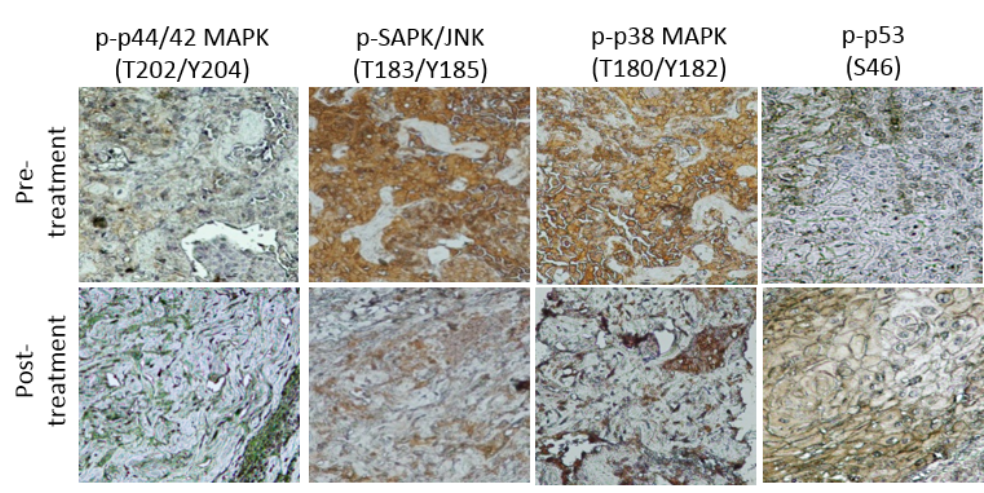

Figure 1: $\beta$-AR antagonism inhibits angiosarcoma viability and mitogenic/survival signaling. (A) Angiosarcoma cell lines were treated with increasing concentrations of the non-selective beta blocker propranolol $(0$ to $200 \mu \mathrm{M})$. Cell viability was measured after 48 hours. (B) SVR cells were treated with a DMSO control or $25 \mu \mathrm{M}$ propranolol for 24 hours. Protein lysates were collected and subjected to immunoblotting to detect levels of key cell cycle regulators. $\beta$-Actin was used as a loading control. (C) SVR cells were treated with $25 \mu \mathrm{M}$ propranolol for 1 hour. Protein lysates were subjected to duplicate antibody arrays that simultaneously detected the relative phosphorylation of 24 kinases. The normalized levels of the phosphorylated proteins across the treatments are visualized via a heat map (red=increased phosphorylation, green=decreased phosphorylation). (D) Angiosarcoma xenografts were injected with an isotonic saline control or propranolol $(15 \mathrm{mg} / \mathrm{kg})$. Cell lysates were collected at 15 minutes post-treatment and subjected to immunoblotting for key mitogenic and survival signaling regulators. $\beta$-actin was used as a control to ensure equal loading of the samples. (E) Tumor sections from an angiosarcoma patient collected at diagnostic biopsy (before propranolol administration, pre-treatment) and at one week after administration of propranolol (120 mg/day) were analyzed by IHC to determine the levels of p-p44/42 (Thr202/Tyr204), p-SAPK/JNK (Thr183/Tyr185), p-p38 (T180/Y182), and p-p53 (S46). Brown coloration indicates positive antigen staining. 

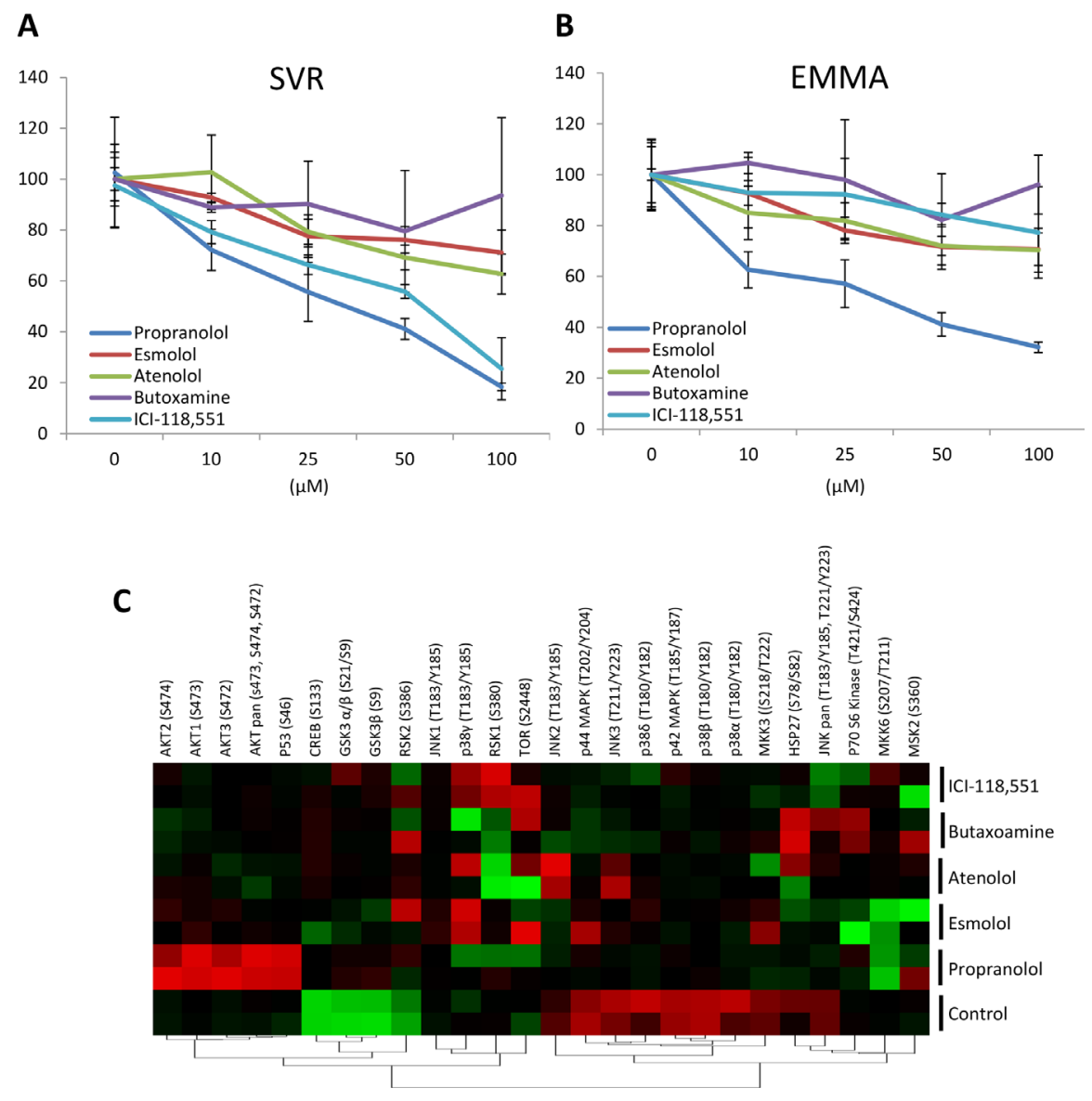

Figure 2: Non-selective $\beta$-AR antagonists reduce angiosarcoma cell viability more effectively than selective antagonists. $(A \&$ B) Two angiosarcoma cell lines, SVR and Emma, were treated with equimolar $(25 \mu \mathrm{M})$ combinations of propranolol $(\beta 1-A R$ and $\beta 2$-AR antagonist), esmolol ( $\beta 1$-AR selective antagonist), atenolol ( $\beta 1$-AR selective antagonist), butoxamine ( $\beta 2$-AR selective antagonist), or ICI-118,551 ( $\beta 2$-AR selective antagonist). Cell viability was assessed after 48 hours of treatment. (C) SVR cells were treated with equimolar $(25 \mu \mathrm{M})$ concentrations of propranolol, esmolol, atenolol, butoxamine, or ICI-118,551 for 1 hour. Protein lysates were analyzed in duplicate using an antibody array that simultaneously detects the relative phosphorylation of 24 kinases. The normalized levels of the phosphorylated proteins across the treatments were visualized via a heat map (red=increased phosphorylation, green=decreased phosphorylation).
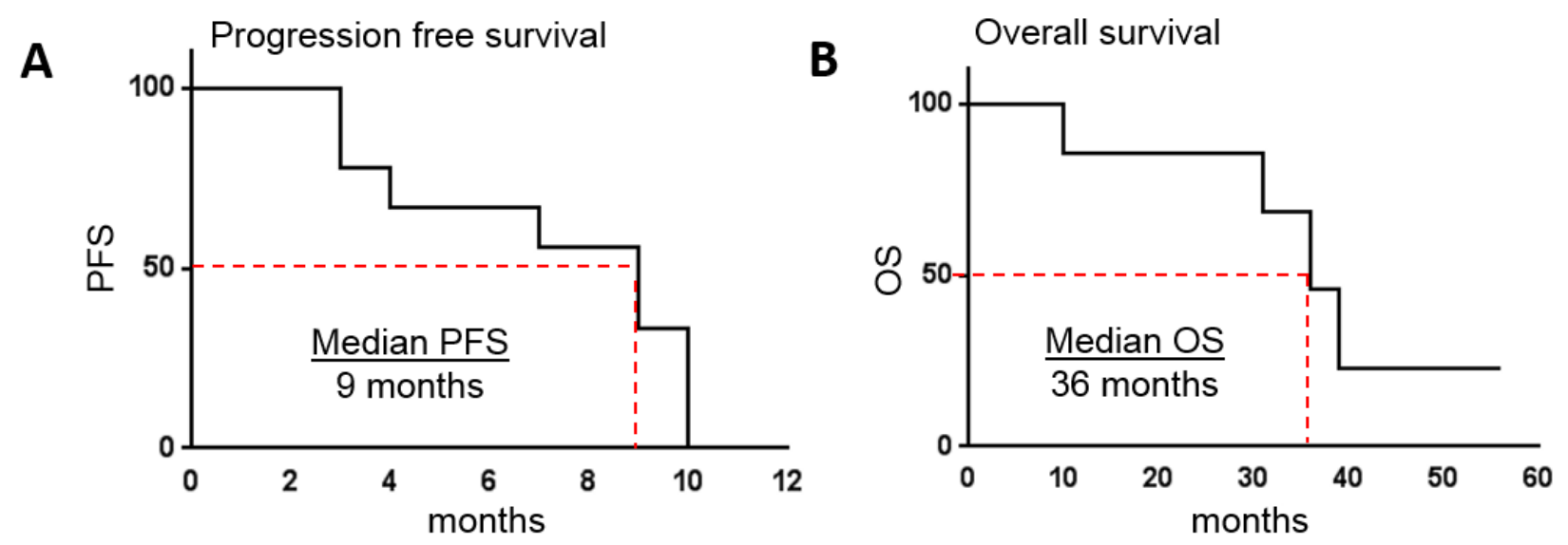

Figure 3: Non-selective $\beta$-AR antagonists increase PSF and OS in patients with metastatic angiosarcoma. Patients with an initial diagnosis of metastatic angiosarcoma were prescribed the non-selective beta blockers propranolol $(n=8)$ or carvedilol $(n=1)$ in addition to their standard anti-cancer treatment regimen. PFS (A) and OS (B) were tracked between the years of 2013 to 2017. 
non-selective $\beta$-AR antagonist propranolol, the $\beta 1$ AR selective antagonist esmolol, the $\beta 1-\mathrm{AR}$ selective antagonist atenolol, the $\beta 2-\mathrm{AR}$ selective antagonist butoxamine, and the $\beta 2-\mathrm{AR}$ selective antagonist ICI118,551 were used at the concentration and timing as indicated for each experiment.

Viability assays. To measure viability, cells were plated in 24 well plates at $0.3 \times 10^{6}$ cells/well, treated as indicated for each experiment, and cell viability was monitored over a 48 hour time course using time lapse microscopy with a Nikon Biostation CT robot. Cell number was manually counted at $\mathrm{t}=0$ hours and $\mathrm{t}=48$ hours. The difference in cell number was used to reflect the viability change for each condition. At least three biological replicates were performed for every cell line, with at least four technical replicates per assay. Data is presented as the average of the technical replicates for a single biological replicate.

Immunoblotting. Lysates from cell culture or tumor tissue were collected as indicated for each experiment, subjected to SDS-PAGE, and transferred to polyvinylidene fluoride membranes using the Trans-Blot Turbo Transfer System (Bio-Rad). Membranes were blocked in tris buffered saline plus 3\% bovine serum albumin and $0.05 \%$ Tween-20, and incubated with the following antibodies as indicated for each experiment: anti-phospho-p38 (T180/ Y182) (Cell Signaling \#4511), anti-phospho-SAPK/JNK (T183/Y185) (Cell Signaling \#4668), anti-phospho-p44/42 (T202/Y204) (Cell Signaling \#4370), anti-phospho-p53 (S46) (Cell Signaling \#2521), anti-cyclin D1 (Cell Signaling \#2978), anti-cyclin D3 (Cell Signaling \#2936), anti-CDK4 (Cell Signaling \#12790), anti-CDK6 (Cell Signaling \#13331), anti-p21 (Cell Signaling \#2947), anti-p27 (Cell Signaling \#3686), and anti- $\beta$ actin (Santa Cruz Biotech \#sc8432). Each primary antibody was detected with an appropriate 1:1000 HRP-conjugated secondary antibody, subjected to Supersignal West Dura Extended Duration Substrate (ThermoFisher Scientific \#34075), and digitally captured using a GE Image Quant Las4000 imaging system.

Antibody array. The Phospho-Mitogen-Activated Protein Kinase (MAPK) Antibody Array (R\&D Systems \#ARY002B) was performed according to the manufacturer's instructions using SVR cell lysates. Densitometry of each antibody array signal was performed using ImageJ software. Reference spots on each array were used to normalize the pixel densities. The numerical protein expression data was normalized, and centroid linkage based on an uncentered correlation similarity metric was performed using Gene Cluster 3.0 software. Heatmaps were generated using JavaTreeView software.

Animal models. Animal experiments were performed in accordance to Texas Tech University Health Sciences Center Institutional Animal Care and Use Committee regulations for the care and use of animals in experimental procedures, and all efforts were made to minimize suffering. Mice were housed 4 per cage in a temperature-controlled animal facility on a $12 \mathrm{~h}-12 \mathrm{~h}$ light-dark cycle. Animals had free access to mouse chow and water. Xenograft angiosarcoma tumor models were generated via subcutaneous injection of $1 \times 105$ SVR cells into the dorsolateral flank of 6 week old male $\mathrm{J} / \mathrm{Nu}$ mice ( $\mathrm{N}=5$ mice per experimental condition). Tumors were allowed to grow until $\sim 1 \mathrm{~cm} 3$, and injected with saline sham or $15 \mathrm{mg} / \mathrm{kg}$ propranolol for 15 minutes. Tumor tissue was collected and immediately flash frozen in liquid nitrogen. Tissue lysates were pooled prior to use in immunoblotting.

Immunohistochemistry (IHC). IHC was performed on tumor tissue samples collected from an angiosarcoma patient before and after one week of treatment with propranolol [32]. The following antibodies were used: anti-p-p44/42 (Thr202/Tyr204) (Cell Signaling \#4370), anti-p-SAPK/JNK (Thr183/Tyr185) (Cell Signaling \#4668), anti-p-p38 (T180/Y182) (Abcam \#4822), and anti-phospho-p53 (S46) (Cell Signaling \#2521). Antigenicity was detected using the mouse and rabbit Specific HRP/DAB (ABC) Detection IHC Kit (Abcam \#ab64264) according to the manufacturer's protocol.

Clinical study. This clinical study was approved by the Texas Tech University Health Sciences Center Institutional Review Board (IRB\# E17109). As angiosarcoma is a very rare tumor and most individual clinical sites do not see enough patients with this tumor type to accommodate a clinical trial, we recruited nine angiosarcoma patients (six women and three men) with a diagnosis of metastatic disease through the Angiosarcoma Awareness patient support group on Facebook. The median age for this cohort was 55 years with a range from 34 to 75 years. Similar recruitment strategies using social media have been effective for a number of rare diseases where any single treatment center would lack the patient volume necessary to conduct a clinical study [68-73]. PFS and OS were obtained for each patient, and the data were compared to historical controls (25 years of data describing clinical outcomes in angiosarcoma patients treated at the Memorial Sloan Kettering Cancer Center) [4]. Kaplan-Meier plots were generated and statistical analysis was performed using GraphPad Prism 7.03. The Pearson's correlation coefficient for PFS and dose of propranolol was calculated using Microsoft Excel.

\section{CONCLUSION}

Due to the poor prognosis of metastatic angiosarcoma patients, many are faced with the decision to undergo chemotherapy, radiation, and/or surgery or simply accept supportive care-choices that generally lead to similar outcomes. The data presented in this study suggest that incorporation of non-selective $\beta$-AR antagonists into a variety of standard treatment regimens enhances PFS and OS in patients with metastatic angiosarcoma. Use 
of inexpensive and relatively safe non-selective $\beta$-AR antagonists along with established treatments against angiosarcoma could improve prognoses for metastatic patients.

\section{FUNDING}

This work was supported by grants from Angiosarcoma Awareness Foundation (BAB) and Sarcoma Foundation of America (BAB and EBD).

\section{REFERENCES}

1. Young RJ, Brown NJ, Reed MW, Hughes D, Woll PJ. Angiosarcoma. Lancet Oncol. 2010; 11: 983-91. doi: 10.1016/S1470-2045(10)70023-1.

2. Scow JS, Reynolds CA, Degnim AC, Petersen IA, Jakub JW, Boughey JC. Primary and secondary angiosarcoma of the breast: the Mayo Clinic experience. J Surg Oncol. 2010; 101: 401-7. doi: 10.1002/jso.21497.

3. Buehler D, Rice SR, Moody JS, Rush P, Hafez GR, Attia S, Longley BJ, Kozak KR. Angiosarcoma outcomes and prognostic factors: a 25-year single institution experience. Am J Clin Oncol. 2014; 37: 473-9. doi: 10.1097/ COC.0b013e31827e4e7b.

4. D’Angelo SP, Munhoz RR, Kuk D, Landa J, Hartley EW, Bonafede M, Dickson MA, Gounder M, Keohan ML, Crago AM, Antonescu CR, Tap WD. Outcomes of Systemic Therapy for Patients with Metastatic Angiosarcoma. Oncology. 2015; 89: 205-14. doi: 10.1159/000381917.

5. Italiano A, Cioffi A, Penel N, Levra MG, Delcambre C, Kalbacher E, Chevreau C, Bertucci F, Isambert N, Blay JY, Bui B, Antonescu C, D'Adamo DR, et al. Comparison of doxorubicin and weekly paclitaxel efficacy in metastatic angiosarcomas. Cancer. 2012; 118: 3330-6. doi: 10.1002/ cncr.26599.

6. Penel N, Bui BN, Bay JO, Cupissol D, Ray-Coquard I, Piperno-Neumann S, Kerbrat P, Fournier C, Taieb S, Jimenez M, Isambert N, Peyrade F, Chevreau C, et al. Phase II trial of weekly paclitaxel for unresectable angiosarcoma: the ANGIOTAX Study. J Clin Oncol. 2008; 26: 5269-74. doi: 10.1200/JCO.2008.17.3146.

7. Penel N, Van Glabbeke M, Marreaud S, Ouali M, Blay JY, Hohenberger P. Testing new regimens in patients with advanced soft tissue sarcoma: analysis of publications from the last 10 years. Ann Oncol. 2011; 22: 1266-72. doi: 10.1093/annonc/mdq608.

8. Wang H, Shi J, Liu H, Chen Y, Wang Y, Wang W, Zhang L. Clinical and diagnostic features of angiosarcoma with pulmonary metastases: A retrospective observational study. Medicine (Baltimore). 2017; 96: e8033. doi: 10.1097/ MD.0000000000008033.

9. Agulnik M, Yarber JL, Okuno SH, von Mehren M, Jovanovic BD, Brockstein BE, Evens AM, Benjamin RS. An open-label, multicenter, phase II study of bevacizumab for the treatment of angiosarcoma and epithelioid hemangioendotheliomas. Ann Oncol. 2013; 24: 257-63. doi: 10.1093/annonc/mds237.

10. Dezong G, Zhongbing M, Qinye F, Zhigang Y. Carvedilol suppresses migration and invasion of malignant breast cells by inactivating Src involving cAMP/PKA and PKCdelta signaling pathway. J Cancer Res Ther. 2014; 10: 998-1003. doi: 10.4103/0973-1482.137664.

11. Maki RG, D’Adamo DR, Keohan ML, Saulle M, Schuetze SM, Undevia SD, Livingston MB, Cooney MM, Hensley ML, Mita MM, Takimoto CH, Kraft AS, Elias AD, et al. Phase II study of sorafenib in patients with metastatic or recurrent sarcomas. J Clin Oncol. 2009; 27: 3133-40. doi: 10.1200/JCO.2008.20.4495.

12. Chen D, Xing W, Hong J, Wang M, Huang Y, Zhu C, Yuan $\mathrm{Y}$, Zeng W. The beta2-adrenergic receptor is a potential prognostic biomarker for human hepatocellular carcinoma after curative resection. Ann Surg Oncol. 2012; 19: 355665. doi: 10.1245/s10434-012-2396-1.

13. Chisholm KM, Chang KW, Truong MT, Kwok S, West RB, Heerema-McKenney AE. beta-Adrenergic receptor expression in vascular tumors. Mod Pathol. 2012; 25: 144651. doi: 10.1038/modpathol.2012.108.

14. Du Y, Zhou L, Wang Y, Yan T, Jiang Y, Shao Z, Yin W, Lu J. Association of alpha2a and beta2 adrenoceptor expression with clinical outcome in breast cancer. Curr Med Res Opin. 2014; 30: 1337-44. doi: 10.1185/03007995.2014.890928.

15. Montoya A, Amaya CN, Belmont A, Diab N, Trevino R, Villanueva G, Rains S, Sanchez LA, Badri N, Otoukesh S, Khammanivong A, Liss D, Baca ST, et al. Use of nonselective beta-blockers is associated with decreased tumor proliferative indices in early stage breast cancer. Oncotarget. 2017; 8: 6446-60. doi: 10.18632/oncotarget.14119.

16. Moretti S, Massi D, Farini V, Baroni G, Parri M, Innocenti $\mathrm{S}$, Cecchi R, Chiarugi P. beta-adrenoceptors are upregulated in human melanoma and their activation releases protumorigenic cytokines and metalloproteases in melanoma cell lines. Lab Invest. 2013; 93: 279-90. doi: 10.1038/ labinvest.2012.175.

17. Powe DG, Voss MJ, Habashy HO, Zanker KS, Green AR, Ellis IO, Entschladen F. Alpha- and beta-adrenergic receptor (AR) protein expression is associated with poor clinical outcome in breast cancer: an immunohistochemical study. Breast Cancer Res Treat. 2011; 130: 457-63. doi: 10.1007/s10549-011-1371-z.

18. Schuller HM, Plummer HK, 3rd, Bochsler PN, Dudric P, Bell JL, Harris RE. Co-expression of betaadrenergic receptors and cyclooxygenase- 2 in pulmonary adenocarcinoma. Int J Oncol. 2001; 19: 445-9. doi:

19. Shang ZJ, Liu K, Liang DF. Expression of beta2adrenergic receptor in oral squamous cell carcinoma. J Oral Pathol Med. 2009; 38: 371-6. doi: 10.1111/j.16000714.2008.00691.x.

20. Shimizu A, Kaira K, Mori K, Kato M, Shimizu K, Yasuda M, Takahashi A, Oyama T, Asao T, Ishikawa O. Prognostic 
significance of beta2-adrenergic receptor expression in malignant melanoma. Tumour Biol. 2016; 37: 5971-8. doi: 10.1007/s13277-015-4420-0.

21. Stiles JM, Amaya C, Rains S, Diaz D, Pham R, Battiste J, Modiano JF, Kokta V, Boucheron LE, Mitchell DC, Bryan BA. Targeting of beta adrenergic receptors results in therapeutic efficacy against models of hemangioendothelioma and angiosarcoma. PLoS One. 2013; 8: e60021. doi: 10.1371/journal.pone.0060021.

22. Wang HY, Berrios $\mathrm{M}$, Malbon CC. Indirect immunofluorescence localization of beta-adrenergic receptors and G-proteins in human A431 cells. Biochem J. 1989; 263: 519-32.

23. Rains SL, Amaya CN, Bryan BA. Beta-adrenergic receptors are expressed across diverse cancers. Oncoscience. 2017; 4: 95-105. doi: 10.18632/oncoscience. 357 .

24. Coelho M, Soares-Silva C, Brandao D, Marino F, Cosentino M, Ribeiro L. beta-Adrenergic modulation of cancer cell proliferation: available evidence and clinical perspectives. J Cancer Res Clin Oncol. 2017; 143: 275-91. doi: 10.1007/ s00432-016-2278-1.

25. Dickerson E, Bryan B. Beta Adrenergic Signaling: A Targetable Regulator of Angiosarcoma and Hemangiosarcoma. Veterinary Sciences. 2015; 2: 270.

26. Krizanova O, Babula P, Pacak K. Stress, catecholaminergic system and cancer. Stress. 2016; 19: 419-28. doi: $10.1080 / 10253890.2016 .1203415$.

27. Leaute-Labreze C, Boccara O, Degrugillier-Chopinet C, Mazereeuw-Hautier J, Prey S, Lebbe G, Gautier S, Ortis V, Lafon M, Montagne A, Delarue A, Voisard JJ. Safety of Oral Propranolol for the Treatment of Infantile Hemangioma: A Systematic Review. Pediatrics. 2016; 138. doi: 10.1542/peds.2016-0353.

28. Pantziarka P, Bouche G, Sukhatme V, Meheus L, Rooman I, Sukhatme VP. Repurposing Drugs in Oncology (ReDO)Propranolol as an anti-cancer agent. Ecancermedicalscience. 2016; 10: 680. doi: 10.3332/ecancer.2016.680.

29. Leaute-Labreze C, Dumas de la Roque E, Hubiche T, Boralevi F, Thambo JB, Taieb A. Propranolol for severe hemangiomas of infancy. N Engl J Med. 2008; 358: 264951. doi: 10.1056/NEJMc0708819.

30. Stiles J, Amaya C, Pham R, Rowntree RK, Lacaze M, Mulne A, Bischoff J, Kokta V, Boucheron LE, Mitchell DC, Bryan BA. Propranolol treatment of infantile hemangioma endothelial cells: A molecular analysis. Exp Ther Med. 2012; 4: 594-604. doi: 10.3892/etm.2012.654.

31. Banavali S, Pasquier E, Andre N. Targeted therapy with propranolol and metronomic chemotherapy combination: sustained complete response of a relapsing metastatic angiosarcoma. Ecancermedicalscience. 2015; 9: 499. doi: 10.3332/ecancer.2015.499.

32. Chow W, Amaya CN, Rains S, Chow M, Dickerson EB, Bryan BA. Growth Attenuation of Cutaneous Angiosarcoma With Propranolol-Mediated beta-Blockade.
JAMA Dermatol. 2015; 151: 1226-9. doi: 10.1001/ jamadermatol.2015.2554.

33. Daguze J, Saint-Jean M, Dreno B. Large nose angiosarcoma treated effectively with oral cyclophosphamide combined with propranolol. J Eur Acad Dermatol Venereol. 2017. doi: 10.1111/jdv.14528.

34. Daguze J, Saint-Jean M, Peuvrel L, Cassagnau E, Quereux G, Khammari A, Dreno B. Visceral metastatic angiosarcoma treated effectively with oral cyclophosphamide combined with propranolol. JAAD Case Rep. 2016; 2: 497-9. doi: 10.1016/j.jdcr.2016.10.005.

35. Filippi L, Tamburini A, Berti E, Perrone A, Defilippi C, Favre C, Calvani M, Della Bona ML, la Marca G, Donzelli G. Successful Propranolol Treatment of a Kaposiform Hemangioendothelioma Apparently Resistant to Propranolol. Pediatr Blood Cancer. 2016; 63: 1290-2. doi: 10.1002/pbc.25979.

36. Pasquier E, Andre N, Street J, Chougule A, Rekhi B, Ghosh J, Philip DSJ, Meurer M, MacKenzie KL, Kavallaris M, Banavali SD. Effective Management of Advanced Angiosarcoma by the Synergistic Combination of Propranolol and Vinblastine-based Metronomic Chemotherapy: A Bench to Bedside Study. EBioMedicine. 2016; 6: 87-95. doi: 10.1016/j.ebiom.2016.02.026.

37. Pramanik R, Gogia A, Malik PS, Gogi R. Metastatic Primary Angiosarcoma of the Breast: Can We Tame It the Metronomic Way. Indian J Med Paediatr Oncol. 2017; 38: 228-31. doi: 10.4103/ijmpo.ijmpo_156_16.

38. Wang Z, Li K, Dong K, Xiao X, Zheng S. Variable response to propranolol treatment of kaposiform hemangioendothelioma, tufted angioma, and KasabachMerritt phenomenon. Pediatr Blood Cancer. 2014; 61: 1518-9. doi: 10.1002/pbc.24957.

39. Lamkin DM, Sung HY, Yang GS, David JM, Ma JC, Cole SW, Sloan EK. alpha2-Adrenergic blockade mimics the enhancing effect of chronic stress on breast cancer progression. Psychoneuroendocrinology. 2015; 51: 262-70. doi: 10.1016/j.psyneuen.2014.10.004.

40. Pasquier E, Ciccolini J, Carre M, Giacometti S, Fanciullino R, Pouchy C, Montero MP, Serdjebi C, Kavallaris M, Andre N. Propranolol potentiates the anti-angiogenic effects and anti-tumor efficacy of chemotherapy agents: implication in breast cancer treatment. Oncotarget. 2011; 2: 797-809. doi: 10.18632/oncotarget.343.

41. Wilson JM, Lorimer E, Tyburski MD, Williams CL. beta-Adrenergic receptors suppress Rap1B prenylation and promote the metastatic phenotype in breast cancer cells. Cancer Biol Ther. 2015; 16: 1364-74. doi: 10.1080/15384047.2015.1070988.

42. Pasquier E, Street J, Pouchy C, Carre M, Gifford AJ, Murray J, Norris MD, Trahair T, Andre N, Kavallaris M. beta-blockers increase response to chemotherapy via direct antitumour and anti-angiogenic mechanisms in neuroblastoma. Br J Cancer. 2013; 108: 2485-94. doi: 10.1038/bjc.2013.205. 
43. Dal Monte M, Casini G, Filippi L, Nicchia GP, Svelto M, Bagnoli P. Functional involvement of beta3-adrenergic receptors in melanoma growth and vascularization. J Mol Med (Berl). 2013; 91: 1407-19. doi: 10.1007/s00109-0131073-6.

44. Jean Wrobel L, Bod L, Lengagne R, Kato M, PrevostBlondel A, Le Gal FA. Propranolol induces a favourable shift of anti-tumor immunity in a murine spontaneous model of melanoma. Oncotarget. 2016; 7: 77825-37. doi: 10.18632/oncotarget. 12833.

45. Maccari S, Buoncervello M, Rampin A, Spada M, Macchia D, Giordani L, Stati T, Bearzi C, Catalano L, Rizzi R, Gabriele L, Marano G. Biphasic effects of propranolol on tumour growth in B16F10 melanoma-bearing mice. Br J Pharmacol. 2017; 174: 139-49. doi: 10.1111/bph.13662.

46. Sereni F, Dal Monte M, Filippi L, Bagnoli P. Role of host beta1- and beta2-adrenergic receptors in a murine model of B16 melanoma: functional involvement of beta3-adrenergic receptors. Naunyn Schmiedebergs Arch Pharmacol. 2015; 388: 1317-31. doi: 10.1007/s00210-015-1165-7.

47. Wnorowski A, Sadowska M, Paul RK, Singh NS, Boguszewska-Czubara A, Jimenez L, Abdelmohsen K, Toll L, Jozwiak K, Bernier M, Wainer IW. Activation of beta2-adrenergic receptor by (R,R')-4'-methoxy-1naphthylfenoterol inhibits proliferation and motility of melanoma cells. Cell Signal. 2015; 27: 997-1007. doi: 10.1016/j.cellsig.2015.02.012.

48. Zhou C, Chen X, Zeng W, Peng C, Huang G, Li X, Ouyang Z, Luo Y, Xu X, Xu B, Wang W, He R, Zhang X, et al. Propranolol induced G0/G1/S phase arrest and apoptosis in melanoma cells via AKT/MAPK pathway. Oncotarget. 2016; 7: 68314-27. doi: 10.18632/oncotarget.11599.

49. Armaiz-Pena GN, Allen JK, Cruz A, Stone RL, Nick AM, Lin YG, Han LY, Mangala LS, Villares GJ, Vivas-Mejia P, Rodriguez-Aguayo C, Nagaraja AS, Gharpure KM, et al. Src activation by beta-adrenoreceptors is a key switch for tumour metastasis. Nat Commun. 2013; 4: 1403. doi: $10.1038 /$ ncomms 2413 .

50. Barron TI, Connolly RM, Sharp L, Bennett K, Visvanathan $\mathrm{K}$. Beta blockers and breast cancer mortality: a populationbased study. J Clin Oncol. 2011; 29: 2635-44. doi: 10.1200/ JCO.2010.33.5422.

51. Diaz ES, Karlan BY, Li AJ. Impact of beta blockers on epithelial ovarian cancer survival. Gynecol Oncol. 2012; 127: 375-8. doi: 10.1016/j.ygyno.2012.07.102.

52. Grytli HH, Fagerland MW, Fossa SD, Tasken KA. Association between use of beta-blockers and prostate cancer-specific survival: a cohort study of 3561 prostate cancer patients with high-risk or metastatic disease. Eur Urol. 2014; 65: 635-41. doi: 10.1016/j.eururo.2013.01.007.

53. Grytli HH, Fagerland MW, Fossa SD, Tasken KA, Haheim LL. Use of beta-blockers is associated with prostate cancerspecific survival in prostate cancer patients on androgen deprivation therapy. Prostate. 2013; 73: 250-60. doi: $10.1002 /$ pros. 22564 .
54. Lemeshow S, Sorensen HT, Phillips G, Yang EV, Antonsen S, Riis AH, Lesinski GB, Jackson R, Glaser R. beta-Blockers and survival among Danish patients with malignant melanoma: a population-based cohort study. Cancer Epidemiol Biomarkers Prev. 2011; 20: 2273-9. doi: 10.1158/1055-9965.EPI-11-0249.

55. Melhem-Bertrandt A, Chavez-Macgregor M, Lei X, Brown EN, Lee RT, Meric-Bernstam F, Sood AK, Conzen SD, Hortobagyi GN, Gonzalez-Angulo AM. Beta-blocker use is associated with improved relapse-free survival in patients with triple-negative breast cancer. J Clin Oncol. 2011; 29: 2645-52. doi: 10.1200/JCO.2010.33.4441.

56. Powe DG, Voss MJ, Zanker KS, Habashy HO, Green AR, Ellis IO, Entschladen F. Beta-blocker drug therapy reduces secondary cancer formation in breast cancer and improves cancer specific survival. Oncotarget. 2010; 1: 628-38. doi: 10.18632/oncotarget.101009.

57. Thiele M, Albillos A, Abazi R, Wiest R, Gluud LL, Krag A. Non-selective beta-blockers may reduce risk of hepatocellular carcinoma: a meta-analysis of randomized trials. Liver Int. 2015; 35: 2009-16. doi: 10.1111/liv.12782.

58. Watkins JL, Thaker PH, Nick AM, Ramondetta LM, Kumar S, Urbauer DL, Matsuo K, Squires KC, Coleman RL, Lutgendorf SK, Ramirez PT, Sood AK. Clinical impact of selective and nonselective beta-blockers on survival in patients with ovarian cancer. Cancer. 2015; 121: 3444-51. doi: 10.1002/cncr.29392.

59. Shaashua L, Shabat-Simon M, Haldar R, Matzner P, Zmora O, Shabtai M, Sharon E, Allweis T, Barshack I, Hayman L, Arevalo J, Ma J, Horowitz M, et al. Perioperative COX2 and beta-Adrenergic Blockade Improves Metastatic Biomarkers in Breast Cancer Patients in a Phase-II Randomized Trial. Clin Cancer Res. 2017; 23: 4651-61. doi: 10.1158/1078-0432.CCR-17-0152.

60. Arbiser JL, Bingaman A, Durham M, Cowan S, Cohen C, Zarnegar E, Varma V, Larsen CP. SVR angiosarcomas can be rejected by CD4 costimulation dependent and CD8 costimulation independent pathways. Mol Med. 2002; 8: 551-8.

61. Arbiser JL, Moses MA, Fernandez CA, Ghiso N, Cao Y, Klauber N, Frank D, Brownlee M, Flynn E, Parangi S, Byers HR, Folkman J. Oncogenic H-ras stimulates tumor angiogenesis by two distinct pathways. Proc Natl Acad Sci U S A. 1997; 94: 861-6.

62. Schappa JT, Frantz AM, Gorden BH, Dickerson EB, Vallera DA, Modiano JF. Hemangiosarcoma and its cancer stem cell subpopulation are effectively killed by a toxin targeted through epidermal growth factor and urokinase receptors. Int J Cancer. 2013; 133: 1936-44. doi: 10.1002/ ijc. 28187.

63. Kim JH, Frantz AM, Anderson KL, Graef AJ, Scott MC, Robinson S, Sharkey LC, O'Brien TD, Dickerson EB, Modiano JF. Interleukin-8 promotes canine hemangiosarcoma growth by regulating the tumor microenvironment. Exp Cell Res. 2014; 323: 155-64. doi: 
10.1016/j.yexcr.2014.02.020.

64. Akhtar N, Padilla ML, Dickerson EB, Steinberg H, Breen M, Auerbach R, Helfand SC. Interleukin-12 inhibits tumor growth in a novel angiogenesis canine hemangiosarcoma xenograft model. Neoplasia. 2004; 6: 106-16. doi: 10.1593/ neo.03334.

65. Masuzawa M, Fujimura T, Tsubokawa M, Nishiyama S, Katsuoka K, Terada E, Kunita S, Sakurai Y, Kato H. Establishment of a new murine-phenotypic angiosarcoma cell line (ISOS-1). J Dermatol Sci. 1998; 16: 91-8.

66. Masuzawa M, Fujimura T, Hamada Y, Fujita Y, Hara H, Nishiyama S, Katsuoka K, Tamauchi H, Sakurai Y. Establishment of a human hemangiosarcoma cell line (ISOHAS). Int J Cancer. 1999; 81: 305-8.

67. Italiano A, Chen CL, Thomas R, Breen M, Bonnet F, Sevenet N, Longy M, Maki RG, Coindre JM, Antonescu CR. Alterations of the p53 and PIK3CA/AKT/mTOR pathways in angiosarcomas: a pattern distinct from other sarcomas with complex genomics. Cancer. 2012; 118: 5878-87. doi: 10.1002/cncr.27614.

68. Javaid MK, Forestier-Zhang L, Watts L, Turner A, Ponte C, Teare H, Gray D, Gray N, Popert R, Hogg J, Barrett J, Pinedo-Villanueva R, Cooper C, et al. The RUDY study platform - a novel approach to patient driven research in rare musculoskeletal diseases. Orphanet J Rare Dis. 2016; 11: 150. doi: 10.1186/s13023-016-0528-6.

69. Sasaki K, Hitora T, Nakamura O, Kono R, Yamamoto T. The role of MAPK pathway in bone and soft tissue tumors. Anticancer Res. 2011; 31: 549-53.

70. Schumacher KR, Stringer KA, Donohue JE, Yu S, Shaver A, Caruthers RL, Zikmund-Fisher BJ, Fifer C, Goldberg C, Russell MW. Social media methods for studying rare diseases. Pediatrics. 2014; 133: e1345-53. doi: 10.1542/ peds.2013-2966.

71. Sugawara Y, Narimatsu H, Hozawa A, Shao L, Otani K, Fukao A. Cancer patients on Twitter: a novel patient community on social media. BMC Res Notes. 2012; 5: 699. doi: 10.1186/1756-0500-5-699.

72. Svenstrup D, Jorgensen HL, Winther O. Rare disease diagnosis: A review of web search, social media and largescale data-mining approaches. Rare Dis. 2015; 3: e1083145. doi: 10.1080/21675511.2015.1083145.

73. Thompson MA, Younes A, Miller RS. Using social media in oncology for education and patient engagement. Oncology (Williston Park). 2012; 26: 782, 4-5, 91.

74. Flint MS, Baum A, Episcopo B, Knickelbein KZ, Liegey Dougall AJ, Chambers WH, Jenkins FJ. Chronic exposure to stress hormones promotes transformation and tumorigenicity of 3T3 mouse fibroblasts. Stress. 2013; 16: 114-21. doi: 10.3109/10253890.2012.686075.

75. Lamy S, Lachambre MP, Lord-Dufour S, Beliveau R. Propranolol suppresses angiogenesis in vitro: inhibition of proliferation, migration, and differentiation of endothelial cells. Vascul Pharmacol. 2010; 53: 200-8. doi: 10.1016/j. vph.2010.08.002.

76. Elenkov IJ, Chrousos GP. Stress Hormones, Th1/ Th2 patterns, Pro/Anti-inflammatory Cytokines and Susceptibility to Disease. Trends Endocrinol Metab. 1999; 10: 359-68.

77. Grailer JJ, Haggadone MD, Sarma JV, Zetoune FS, Ward PA. Induction of M2 regulatory macrophages through the beta2-adrenergic receptor with protection during endotoxemia and acute lung injury. J Innate Immun. 2014; 6: 607-18. doi: 10.1159/000358524.

78. Kobayashi M, Jeschke MG, Asai A, Kogiso M, Yoshida S, Herndon DN, Suzuki F. Propranolol as a modulator of M2b monocytes in severely burned patients. J Leukoc Biol. 2011; 89: 797-803. doi: 10.1189/jlb.1010553.

79. Qin JF, Jin FJ, Li N, Guan HT, Lan L, Ni H, Wang Y. Adrenergic receptor beta 2 activation by stress promotes breast cancer progression through macrophages M2 polarization in tumor microenvironment. BMB Rep. 2015; 48: 295-300.

80. Scanzano A, Schembri L, Rasini E, Luini A, Dallatorre J, Legnaro M, Bombelli R, Congiu T, Cosentino M, Marino F. Adrenergic modulation of migration, CD11b and CD18 expression, ROS and interleukin- 8 production by human polymorphonuclear leukocytes. Inflamm Res. 2015; 64: 127-35. doi: 10.1007/s00011-014-0791-8.

81. Takamoto T, Hori Y, Koga Y, Toshima H, Hara A, Yokoyama MM. Norepinephrine inhibits human natural killer cell activity in vitro. Int J Neurosci. 1991; 58: 127-31.

82. Tsuda Y, Kobayashi M, Herndon DN, Suzuki F. Impairment of the host's antibacterial resistance by norepinephrine activated neutrophils. Burns. 2008; 34: 460-6. doi: 10.1016/j.burns.2007.07.004.

83. Vredevoe DL, Moser DK, Gan XH, Bonavida B. Natural killer cell anergy to cytokine stimulants in a subgroup of patients with heart failure: relationship to norepinephrine. Neuroimmunomodulation. 1995; 2: 16-24.

84. Bucsek MJ, Qiao G, MacDonald CR, Giridharan T, Evans L, Niedzwecki B, Liu H, Kokolus KM, Eng JW, Messmer MN, Attwood K, Abrams SI, Hylander BL, et al. beta-adrenergic signaling in mice housed at standard temperatures suppresses an effector phenotype in $\mathrm{CD} 8+\mathrm{T}$ cells and undermines checkpoint inhibitor therapy. Cancer Res. 2017. doi: 10.1158/0008-5472.CAN-17-0546. 